\title{
PENERAPAN SAR PADA UPAH MINIMUM KABUPATEN/KOTA DI PULAU KALIMANTAN TAHUN 2017
}

\author{
(SAR Application in Minimum Wages of The District/Regency in Kalimantan Island 2017)
}

\author{
Irma Yunita ${ }^{1}$, Timbang Sirait ${ }^{2}$ \\ Politeknik Statistika STIS ${ }^{1}$ \\ Politeknik Statistika STIS ${ }^{2}$ \\ Jalan Otto Iskandardinata No. 64C, Jakarta Timur 13330, Indonesia \\ E-mail: 15.8672@stis.ac.id
}

\begin{abstract}
ABSTRAK
Upah minimum suatu wilayah akan merepresentasikan kesejahteraan di wilayah tersebut, di mana semakin tinggi tingkat upah minimum di suatu wilayah maka akan semakin sejahtera pula masyarakatnya. Pada tahun 2017, empat dari lima provinsi di Pulau Kalimantan memiliki besaran upah minimum yang lebih tinggi dari upah nasional serta tidak jauh berbeda nilai upah antar provinsinya, yang mana kemiripan tersebut mencirikan adanya pengaruh spasial pada pulau tersebut. Oleh karena itu, penelitian ini bertujuan untuk mengetahui gambaran umum dan faktor-faktor yang memengaruhi upah minimum dari 56 kabupaten/kota di Pulau Kalimantan pada tahun 2017. Analisis yang digunakan adalah regresi spasial dengan Spatial Autoregressive Model (SAR). Hasil pengujian menunjukkan bahwa keempat variabel independen yang digunakan yaitu jumlah angkatan kerja, pengeluaran per kapita, pertumbuhan ekonomi, serta PDRB memengaruhi upah minimum secara signifikan. Selain itu, upah minimum suatu kabupaten/kota juga berpengaruh secara signifikan dan positif terhadap upah minimum di kabupaten/kota sekitarnya.
\end{abstract}

Kata kunci: Pulau Kalimantan, regresi spasial, Spatial Autoregressive Model, upah minimum

\section{ABSTRACT}

The minimum wage of an area represents the prosperity of the people lived there, where the higher the minimum wage level in an area, the more prosperous people are. In 2017, four out of five provinces in Kalimantan Island had a minimum wage rate that was higher than the national wage and not much different between the provinces' wages, which similarities characterize the spatial effect in that island. Therefore, this study aims to find out the general description and the factors that affect the minimum wage of 56 districts/cities on Kalimantan Island in 2017. The analysis used is spatial regression analysis with the Spatial Autoregressive Model (SAR). The test results show the four independent variables used, which are the number of labor force, expenditure per capita, economic growth, and GRDP affect the minimum wage significantly. In addition, the minimum wage of a district/city also has significant and positive effects on the minimum wage in the surrounding districts/cities.

Keywords: Kalimantan Island, spatial regression, Spatial Autoregressive Model, minimum wage

\section{PENDAHULUAN}

Kesejahteraan merupakan hal yang didambakan oleh semua orang. Setiap orang pasti bercitacita untuk hidup dalam kesejahteraan. Menurut Kamus Besar Bahasa Indonesia (2016), kesejahteraan adalah hal atau keadaan sejahtera; keamanan, keselamatan, ketenteraman. Sementara itu, sejahtera didefinisikan sebagai aman sentosa dan makmur, selamat (terlepas dari segala macam gangguan). Kesejahteraan mencakup keseluruhan aspek dalam kehidupan manusia, seperti ekonomi, sosial, budaya, ilmu pengetahuan dan teknologi, dan lain sebagainya. Tentunya pemerintah berkewajiban untuk meningkatkan kesejahteraan rakyatnya.

Berbagai macam upaya dilakukan pemerintah Indonesia demi kesejahteraan rakyat. Hal tersebut menjadi tujuan nasional bangsa Indonesia sejak dulu, sebagaimana yang tertera dalam amanat konstitusi dalam Pembukaan UUD 1945 alinea keempat, yaitu untuk memajukan kesejahteraan umum. Selain itu, kesejahteraan juga menjadi salah satu tujuan dalam Sustainable Development Goals (SDGs), yaitu tujuan ketiga yang berbunyi: "Memastikan kehidupan yang sehat dan mendukung kesejahteraan bagi semua untuk semua usia". 
Salah satu upaya pemerintah dalam meningkatkan kesejahteraan masyarakat adalah dengan adanya penetapan upah minimum. Melalui penetapan nilai upah yang setiap tahun dinaikkan besarannya, maka diharapkan kesejahteraan masyarakat akan meningkat. Upah minimum yang nilainya berbeda antarwilayah akan merepresentasikan kesejahteraan tiap-tiap wilayah. Semakin tinggi tingkat upah minimum di suatu wilayah, maka semakin sejahtera pula masyarakatnya. Di Indonesia, tiap provinsi menetapkan upah minimum yang berbeda. Berdasarkan data dari Kementerian Ketenagakerjaan dan Transmigrasi, Upah Minimum Provinsi tahun 2017 di Indonesia cukup bervariasi, yaitu dalam rentang 1,3 juta hingga 3,4 juta. Dari 34 provinsi di Indonesia, 16 provinsi di antaranya memiliki Upah Minimum Provinsi di bawah dua juta rupiah, satu provinsi memiliki Upah Minimum Provinsi di atas tiga juta rupiah, dan sisanya berada di antara dua juta dan tiga juta rupiah. Provinsi dengan upah minimum tertinggi yaitu DKI Jakarta, diikuti dengan Papua dan Sulawesi Utara, masing-masing sebesar Rp3.355.750,00, Rp2.663.647,00 dan Rp2.598.000,00. Sedangkan provinsi dengan upah terendah yaitu DI Yogyakarta, Jawa Tengah, dan Jawa Timur, masing-masing sebesar Rp1.337.645,00, Rp1.367.000,00 dan Rp1.388.000,00. Angka tersebut sangat jauh dari rata-rata upah minimum Indonesia, yang nilainya sebesar Rp2.142.885,00. Hal ini menunjukkan ketimpangan dalam hal kesejahteraan.

Salah satu pulau besar di Indonesia yang terdapat provinsi dengan Upah Minimum Provinsi yang tidak jauh berbeda secara kasat mata adalah Pulau Kalimantan. Dibandingkan dengan pulau besar lain di Indonesia, provinsi-provinsi yang berada di Pulau Kalimantan memiliki selisih rentang Upah Minimum Provinsi yang lebih kecil. Bahkan, empat dari lima provinsi di pulau terbesar di Indonesia tersebut memiliki nilai upah minimum provinsi di atas rata-rata upah minimum Indonesia, yaitu apabila dijabarkan Provinsi Kalimantan Barat dengan nilai upah minimum Rp1.882.900, Kalimantan Tengah dengan nilai upah minimum Rp2.227.307,00, Kalimantan Selatan dengan nilai upah minimum Rp2.258.000,00, Kalimantan Timur dengan nilai upah minimum Rp2.339.556,00, dan Kalimantan Utara dengan nilai upah minimum Rp2.354.800,00. Artinya jika dilihat dari segi kesejahteraan, secara rata-rata penduduk di Pulau Kalimantan sudah lebih sejahtera dibandingkan dengan rata-rata penduduk di Indonesia secara keseluruhan.

Kemiripan angka upah minimum pada provinsi-provinsi di Pulau Kalimantan ternyata tidak terlepas dari aspek keruangan atau ketetanggaan, yang dikenal dengan pengaruh atau efek spasial. Sehingga, diduga upah minimum memiliki pengaruh antar wilayah, di mana daerah yang berdekatan cenderung memiliki kesamaan karakteristik. Pernyataan ini sesuai dengan hukum tentang geografi oleh Tobler, bahwa sesuatu yang dekat akan lebih memberikan pengaruh dibandingkan sesuatu yang jauh.

Beberapa penelitian mengenai faktor-faktor yang memengaruhi upah minimum telah dilakukan di Indonesia. Nurtiyas (2016) menemukan bahwa Upah Minimum Provinsi dipengaruhi oleh Tingkat Partisipasi Angkatan Kerja, Produk Domestik Regional Bruto (PDRB), dan pendapatan per kapita. Sementara itu, Nursakinah (2017) menemukan bahwa penetapan upah minimum dipengaruhi oleh Kebutuhan Hidup Layak (KHL), PDRB, dan jumlah pencari kerja.

Penelitian mengenai upah juga dilakukan oleh Kistanto (2013), dengan hasil temuan bahwa penetapan UMK Jember dipengaruhi oleh KHL dan PDRB. Adapun pada tahun yang sama, Charysa (2013) menemukan bahwa pertumbuhan ekonomi dan inflasi secara parsial berpengaruh positif terhadap upah minimum regional di Jawa Tengah.

Secara umum, penelitian mengenai upah minimum sudah cukup banyak dilakukan, namun penelitian yang menggunakan model yang mempertimbangkan pengaruh spasial dari upah tersebut masih jarang. Oleh karena itu, penelitian ini akan menggunakan model yang mampu mengakomodasi pengaruh spasial tersebut di tingkat kabupaten/kota.

Berdasarkan berbagai pertimbangan di atas, penelitian ini bertujuan untuk mengetahui gambaran umum karakteristik Upah Minimum Kabupaten/Kota di 56 kabupaten/kota di Pulau Kalimantan tahun 2017, mengidentifikasi ada atau tidaknya pengaruh spasial pada Upah Minimum Kabupaten/Kota di Pulau Kalimantan tahun 2017, serta mengetahui variabel-variabel yang berpengaruh secara signifikan terhadap Upah Minimum Kabupaten/Kota di Pulau Kalimantan pada tahun 2017. 


\section{METODE}

\section{Metode Pengumpulan Data}

Penelitian ini mencakup 56 kabupaten/kota yang ada di lima provinsi di Pulau Kalimantan dengan periode waktu 2017. Variabel dependen yang digunakan dalam penelitian ini adalah upah minimum tiap kabupaten/kota. Sedangkan variabel independen yang digunakan yaitu jumlah angkatan kerja, pengeluaran per kapita, pertumbuhan ekonomi, dan PDRB. Data yang digunakan dalam penelitian ini adalah data sekunder yang didapatkan dari beberapa sumber, yaitu:

a. Surat Keputusan Gubernur tahun 2016 tentang Upah Minimum dan Upah Minimum Sektoral Kabupaten/Kota untuk memperoleh variabel upah minimum tiap kabupaten/kota.

b. Publikasi Provinsi dalam Angka 2018 dari Badan Pusat Statistik untuk memperoleh variabel jumlah angkatan kerja, pengeluaran per kapita, dan pertumbuhan ekonomi.

c. Pubikasi Tinjauan Regional Berdasarkan PDRB Kabupaten/Kota 2013-2017 - Buku 3 Pulau Kalimantan dari Badan Pusat Statistik untuk memperoleh variabel PDRB.

\section{Metode Analisis}

Penelitian ini menggunakan metode analisis deskriptif dan inferensia. Pada analisis deskriptif, akan disajikan tabel mengenai gambaran umum Upah Minimum Kabupaten/Kota. Selain itu, tiaptiap variabel yang digunakan dalam penelitian ini dibagi menjadi lima kelas interval berdasar jenks natural breaks oleh software ArcGis versi 10.2 yang kemudian akan dibentuk peta tematik.

Pada analisis inferensia, digunakan regresi spasial untuk mengetahui variabel-variabel yang berpengaruh terhadap Upah Minimum Kabupaten/Kota. Regresi spasial dipilih sebagai metode analisis dalam penelitian ini disebabkan unit analisis dalam penelitian ini berupa wilayah, sehingga terindikasi adanya depedensi spasial di dalamnya. Secara garis besar terdapat tiga tahapan pemodelan regresi spasial, yaitu pemodelan variabel menggunakan regresi linear berganda (OLS) dengan pengujian asumsi regresi klasik, identifikasi dan pengujian pengaruh spasial, serta diagnosa dependensi spasial.

Tahap pertama yaitu memodelkan variabel dependen dengan metode regresi OLS, yang sekaligus berfungsi untuk menguji asumsi regresi klasik. Asumsi regresi klasik yang dimaksud yaitu: error data berdistribusi normal, nonmultikolinearitas antar variabel independen, dan homoskedastis. Pengujian asumsi tersebut memiliki tujuan agar persamaan regresi yang diperoleh memiliki ketepatan dalam estimasi, tidak bias, dan konsisten. Lalu untuk menguji apakah data memiliki autokorelasi spasial, dilakukan identifikasi dan pengujian pengaruh spasial yang dilakukan menggunakan Uji Moran's Isecara global dan secara lokal melalui Moran's Scatterplot. Apabila kedua uji signifikan, model regresi OLS tidak lagi tepat untuk digunakan karena estimasi yang dihasilkan akan tidak efisien.

Tahap ketiga yaitu diagnosa dependensi spasial yang memiliki tujuan untuk menentukan jenis model regresi spasial yang sesuai dengan kondisi data penelitian. Diagnosa tersebut dilakukan menggunakan uji Moran's I dan Lagrange Multiplier (LM-Lag dan LM-Error). Jika kedua uji tersebut tidak signifikan, maka digunakan model regresi dengan OLS. Apabila di antara uji LM-Lag dan LMError hanya terdapat satu uji yang signifikan, maka digunakan model yang signifikan tersebut. Apabila kedua uji signifikan pada kedua jenis pemodelan spasial (LM-Lag dan LM-Error) maka perlu uji lanjutan, yaitu menggunakan uji Robust Lagrange Multiplier(RLM-Lag dan RLM-Error). Hasil yang diperoleh, apabila uji RLM-Lag lebih signifikan dibanding RLM-Error maka model terbaik yang digunakan adalah Spatial Lag Model, serta apabila sebaliknya, maka model terbaik yang digunakan adalah Spatial Error Model.

\section{HASIL DAN PEMBAHASAN}

\section{Gambaran Umum Karakteristik Upah Minimum Kabupaten/Kota di Kabupaten/Kota di Pulau Kalimantan Tahun 2017}

Pada tahun 2017, empat dari lima provinsi di Pulau Kalimantan memiliki Upah Minimum Provinsi di atas upah minimum nasional, dengan rata-rata Upah Minimum Kabupaten/Kota penduduknya 
sebesar Rp2.291.820,00. Rentang upah minimum penduduk di Pulau Kalimantan dari yang paling rendah hingga yang paling tinggi adalah Rp1.901.005,00 dan Rp2.948.067,00, masing-masing diduduki oleh Mempawah dan Kota Tarakan. Bila data Upah Minimum Kabupaten/Kota dibagi menjadi dua, penduduk di Pulau Kalimantan ditemukan mendapat upah lebih tinggi dari upah nasional lebih banyak (76,79 persen) dibanding yang mendapat upah di bawah upah nasional $(23,21$ persen).

Adapun karakteristik yang diduga memengaruhi Upah Minimum Kabupaten/Kota adalah jumlah angkatan kerja, pengeluaran per kapita, pertumbuhan ekonomi, serta PDRB. Kelima karakteristik tersebut akan dipaparkan dalam peta tematik yang diklasifikasi menggunakan metode Jenks Natural Breaks Classification.

\section{Upah Minimum Kabupaten/Kota}

Dari Gambar 1 berikut, dapat dilihat bahwa Provinsi Kalimantan Barat memiliki Upah Minimum Kabupaten/Kota dengan kisaran 1,9 juta sampai dengan 2,0 juta dan 2,4 juta sampai dengan 2,6 juta. Provinsi Kalimantan Tengah mendapat Upah Minimum Kabupaten/Kota di kisaran 2,0 juta sampa 2,6 juta. Provinsi Kalimantan Selatan dengan Upah Minimum Kabupaten/Kota di kisaran 2,0 juta sampai dengan 2,4 juta. Sedangkan Kalimantan Timur dan Kalimantan Utara memiliki Upah Minimum Kabupaten/Kota pada kisaran 2,3 juta sampai dengan 2,6 juta. Berdasarkan Gambar 1, tampak bahwa kabupaten dan kota yang memiliki upah minimum yang mirip saling bergerombol, sehingga terindikasi adanya hubungan spasial pada Upah Minimium Kabupaten/Kota.

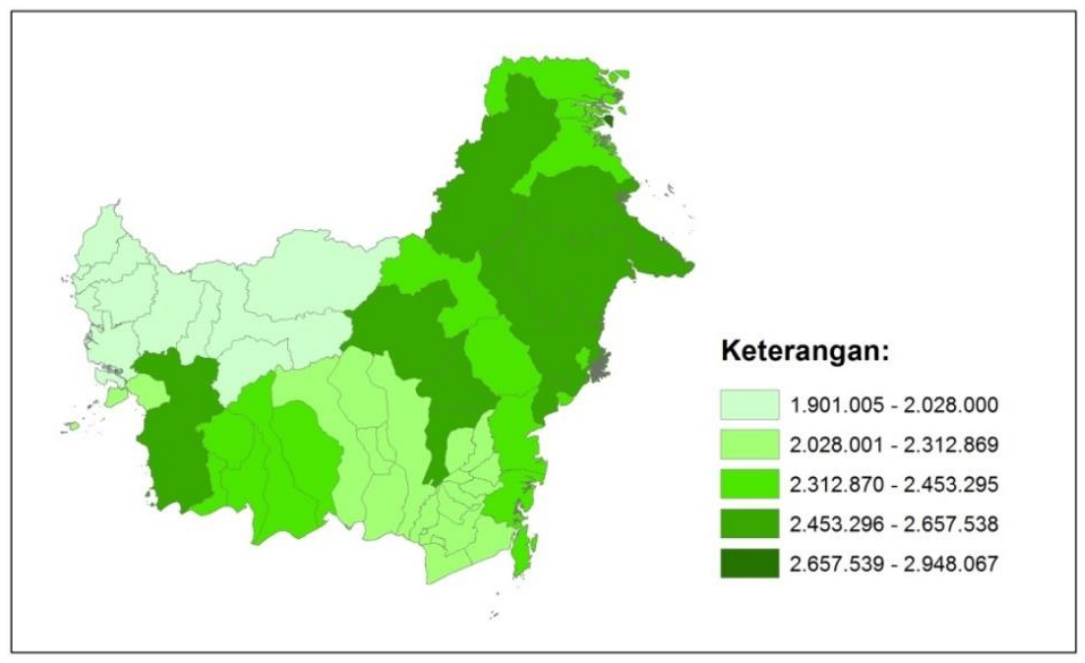

Sumber: Surat Keputusan Gubernur tahun 2016 (diolah)

Gambar 1. Upah Minimum Kabupaten/Kota di Pulau Kalimantan tahun 2017.

2. Jumlah angkatan kerja

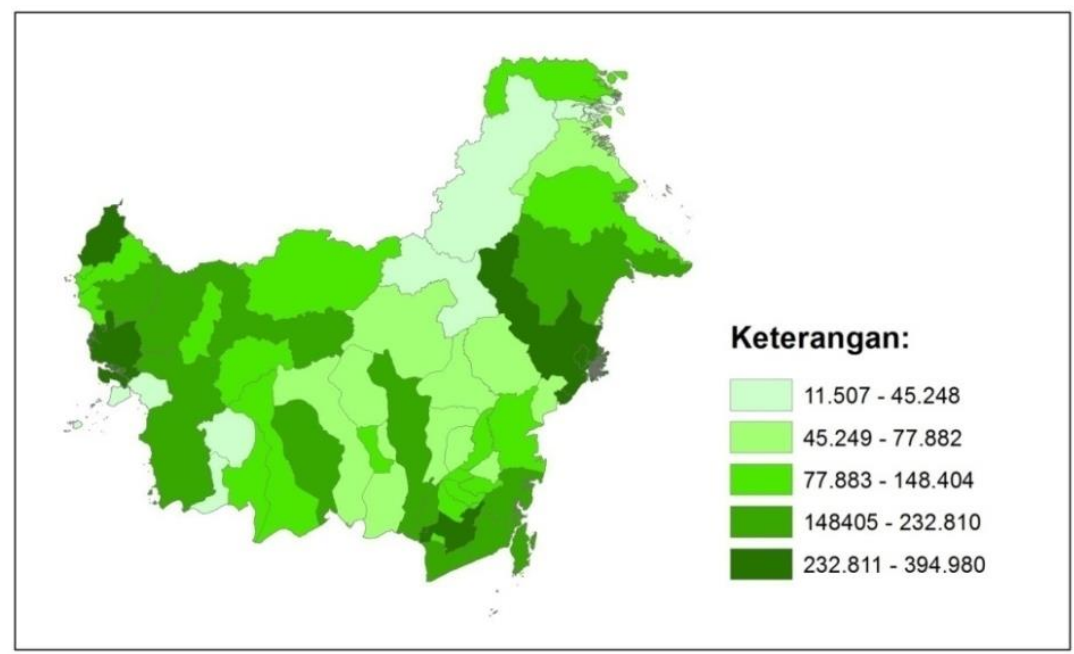

Sumber: Badan Pusat Statistik (diolah)

Gambar 2. Jumlah angkatan kerja kabupaten/kota di Pulau Kalimantan tahun 2017. 
Berdasarkan Gambar 2 di atas, dapat dilihat bahwa sebaran wilayah berdasarkan jumlah angkatan kerja sangat bervariasi. Provinsi Kalimantan Barat, Kalimantan Tengah, Kalimantan Selatan, Kalimantan Timur, dan Kalimantan Utara memiliki kabupaten/kota dengan klasifikasi jumlah angkatan kerja yang bervariasi. Sementara itu, Provinsi Kalimantan Utara didominasi oleh kabupaten/kota dengan jumlah angkatan kerja rendah. Hal ini sesuai jika dibandingkan dengan klasifikasi berdasarkan Upah Minimum Kabupaten/Kota di provinsi tersebut yang didominasi oleh upah yang tinggi. Hal ini mengindikasikan adanya hubungan yang negatif antara Upah Minimum Kabupaten/Kota dengan jumlah angkatan kerja.

\section{Pengeluaran per kapita}

Gambar 3 berikut menunjukkan bahwa sebaran wilayah berdasarkan pengeluaran per kapita sangat bervariasi. Namun pada umumnya, bagian barat Pulau Kalimantan didominasi oleh kabupaten/kota dengan pengeluaran per kapita rendah, sedangkan bagian tengah dan timur Pulau Kalimantan didominasi oleh kabupaten/kota dengan pengeluaran per kapita yang sedang hingga tinggi. Karakteristik ini sejalan dengan klasifikasi berdasarkan Upah Minimum Kabupaten/Kota, yang mana bagian barat Pulau Kalimantan memiliki upah minimum yang rendah dan bagian timur Pulau Kalimantan memiliki upah minimum yang tinggi. Hal ini mengindikasikan adanya hubungan yang positif antara Upah Minimum Kabupaten/Kota dengan pengeluaran per kapita.

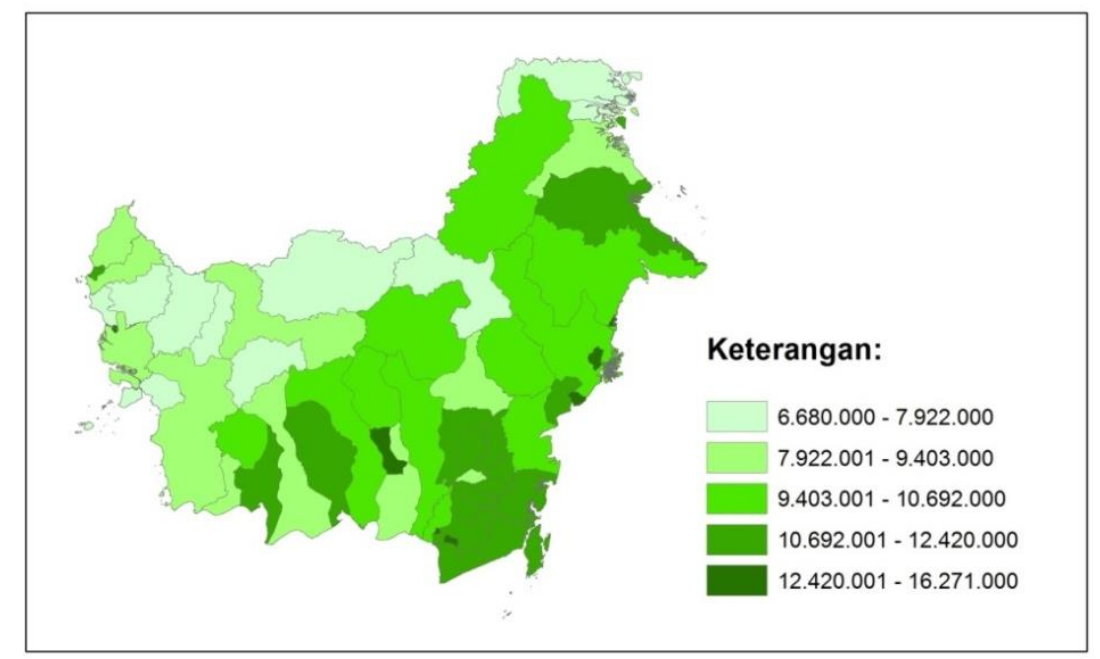

Sumber: Badan Pusat Statistik (diolah)

Gambar 3. Pengeluaran per kapita kabupaten/kota di Pulau Kalimantan tahun 2017.

4. Pertumbuhan ekonomi

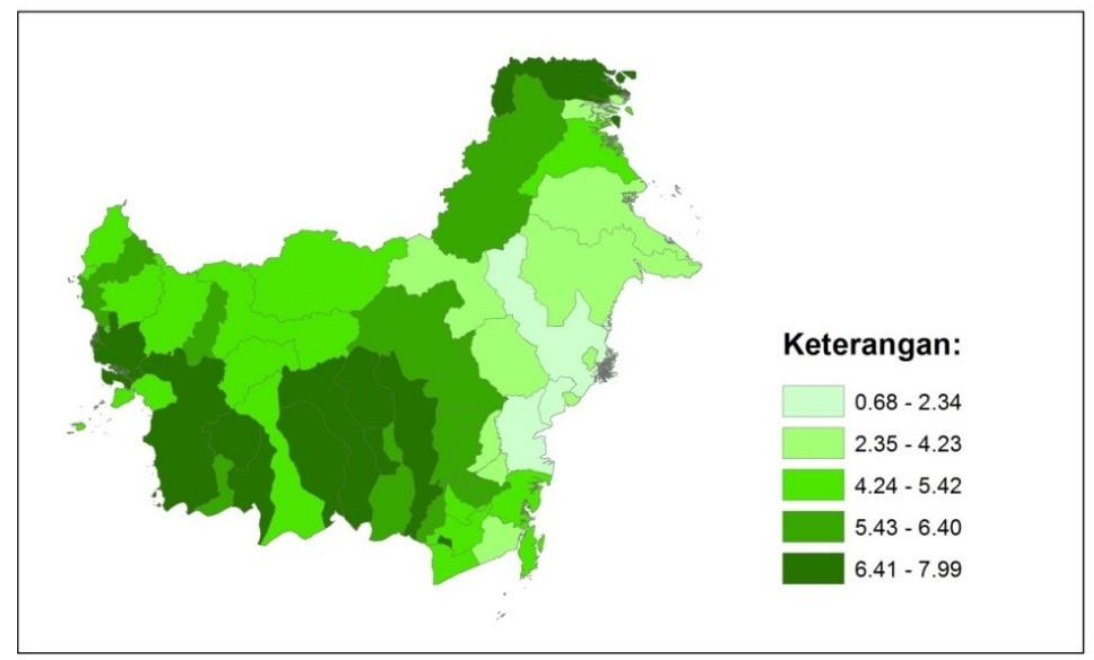

Sumber: Badan Pusat Statistik (diolah)

Gambar 4. Pertumbuhan ekonomi kabupaten/kota di Pulau Kalimantan tahun 2017. 
Gambar 4 di atas merupakan peta tematik yang menggambarkan sebaran kabupaten/kota berdasarkan pertumbuhan ekonomi tahun 2017. Dari Gambar 4, terlihat bahwa sebaran wilayah berdasarkan pertumbuhan ekonomi sangat bervariasi. Namun pada umumnya, Pulau Kalimantan didominasi oleh kabupaten/kota dengan pertumbuhan ekonomi sedang hingga tinggi. Jika dibandingkan dengan klasifikasi berdasarkan Upah Minimum Kabupaten/Kota, terlihat bahwa pertumbuhan ekonomi memiliki pengaruh kecil terhadap Upah Minimum Kabupaten/Kota.

\section{PDRB}

Gambar 5 berikut adalah peta tematik yang menggambarkan sebaran kabupaten/kota berdasarkan PDRB tahun 2017. Dari gambar tersebut, terlihat bahwa sebaran wilayah berdasarkan PDRB cukup bervariasi. Namun pada umumnya, Pulau Kalimantan didominasi oleh kabupaten/kota dengan PDRB rendah. Jika dibandingkan dengan klasifikasi berdasarkan Upah Minimum Kabupaten/Kota, secara kasat mata terlihat bahwa PDRB memiliki pengaruh kecil terhadap Upah Minimum Kabupaten/Kota.

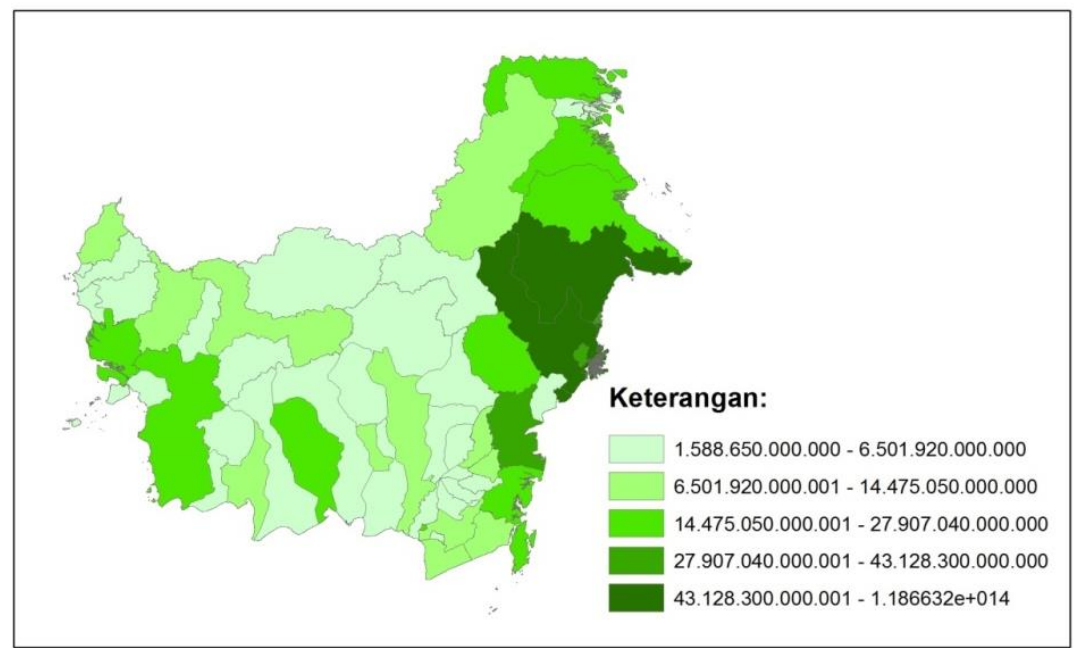

Sumber: Badan Pusat Statistik (diolah)

Gambar 5. PDRB kabupaten/kota di Pulau Kalimantan tahun 2017.

\section{Identifikasi Pengaruh Spasial pada Upah Minimum Kabupaten/Kota di Pulau Kalimantan Tahun 2017}

1. Pengujian Autokorelasi Spasial Global

Pengujian autokorelasi spasial dilakukan dengan menggunakan penimbang spasial queen contiguity yang dimodifikasi secara manual dengan konsep aksesibilitas. Berdasarkan pengujian melalui Global Moran's I, dapat diketahui bahwa terjadi autokorelasi spasial secara positif pada Upah Minimum Kabupaten/Kota di Pulau Kalimantan pada tahun 2017. Hal tersebut ditunjukkan pada Tabel 1 berikut, yaitu dari nilai statistik Global Moran's I yang lebih besar dari nilai ekspektasi Global Moran's $I(0,552>-0,018)$ dan nilai pseudo $p$-value $(0,001)$ lebih kecil dari a lima persen. Oleh karena itu, dapat disimpulkan bahwa terjadi autokorelasi spasial positif pada karakteristik upah minimum antar-kabupaten/kota di Pulau Kalimantan tahun 2017.

Tabel 1. Output GeoDa penghitungan statistik Global Moran's I.

\begin{tabular}{cccc}
\hline Variabel & Statistik Moran's I & $\mathrm{E}(\mathrm{I})$ & Pseudo $p$-value \\
\hline$(1)$ & $(2)$ & $(3)$ & $(4)$ \\
UMK & 0,552 & $-0,018$ & 0,001
\end{tabular}

2. Pengujian Autokorelasi Spasial Lokal

Berdasarkan Gambar 6 berikut, tampak bahwa sebagian besar kabupaten/kota di Pulau Kalimantan memiliki hubungan spasial yang positif atau sebanding untuk karakteristik Upah Minimum Kabupaten/Kota tahun 2017. 


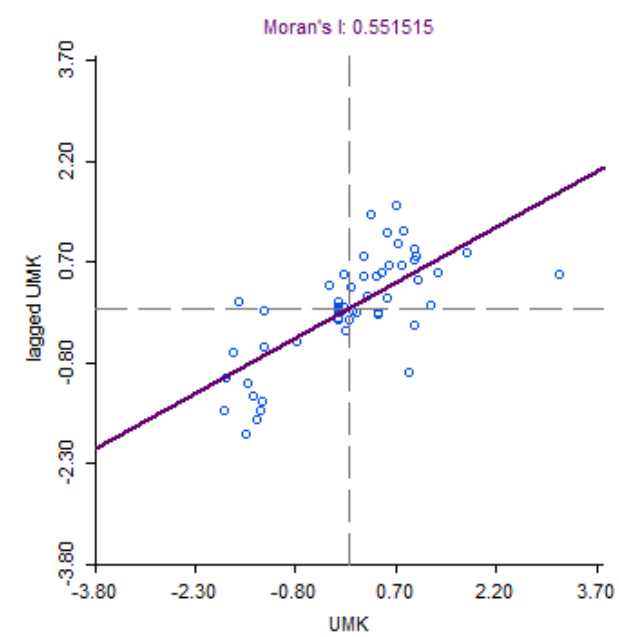

Gambar 6. Moran's scatterplot Upah Minimum Kabupaten/Kota di Pulau Kalimantan tahun 2017.

\section{Variabel-Variabel yang Memengaruhi Upah Minimum Kabupaten/Kota di Pulau Kalimantan pada Tahun 2017}

Variabel dependen yaitu Upah Minimum Kabupaten/Kota diregresikan dengan variabel independennya, yaitu jumlah angkatan kerja, pengeluaran per kapita, pertumbuhan ekonomi, dan PDRB. Pemodelan tersebut menghasilkan nilai $R$-Squared sebesar 0,429 . Angka tersebut memiliki arti bahwa dalam model regresi tersebut, keempat variabel independen yang diujikan mampu menjelaskan 42,9 persen dari Upah Minimum Kabupaten/Kota di Pulau Kalimantan tahun 2017. Selanjutnya, nilai $F$-Statistic menghasilkan probabilitas sebesar 0,000 yang artinya minimal terdapat satu variabel independen dalam model yang signifikan berpengaruh terhadap variabel dependen.

Berdasarkan Tabel 2 berikut, dapat diketahui bahwa dengan tingkat kepercayaan 95 persen, secara parsial hanya variabel jumlah angkatan kerja, pengeluaran per kapita, dan PDRB yang secara signifikan memengaruhi variabel Upah Minimum Kabupaten/Kota, sedangkan variabel pertumbuhan ekonomi tidak signifikan. 
Tabel 2. Ringkasan hasil estimasi parameter regresi OLS

\begin{tabular}{lrrrr}
\multicolumn{1}{c}{ Variabel } & Koefisien $(\beta)$ & Standard Error & \multicolumn{1}{c}{ t-statistics } & \multicolumn{1}{c}{$p$-value } \\
\hline \multicolumn{1}{c}{$(1)$} & \multicolumn{1}{c}{$(2)$} & $(3)$ & \multicolumn{1}{c}{$(4)$} & \multicolumn{1}{c}{$(5)$} \\
Intersep & 1.874 .640 & 148.281 & 12,643 & $0,000^{*}$ \\
AK & $-1,524$ & 0,310 & $-4,913$ & $0,000^{*}$ \\
Peng_Perka & 0,038 & 0,011 & 3,348 & $0,002^{*}$ \\
Eko & $28.681,6$ & $16.859,4$ & 1,701 & 0,095 \\
PDRB & 6,132 & 1,457 & 4,209 & $0,000^{*}$ \\
\hline
\end{tabular}

Keterangan: *) signifikan pada $a=5$ persen

Identifikasi Pengaruh Dependensi Spasial

Berdasarkan hasil penghitungan pada Tabel 3 berikut, statistik Moran's I (error) menunjukkan nilai probabilitas sebesar 0,013 (tolak $\mathrm{H}_{0}$ ), sehingga dapat disimpulkan bahwa terdapat keterkaitan atau dependensi spasial dalam error model regresi OLS. Prosedur selanjutnya yaitu menentukan model spasial yang akan digunakan melalui pengujian Lagrange Multiplier.

Hasil pengujian menunjukkan nilai probabilitas Lagrange Multiplier (lag) sebesar 0,000 (tolak $\mathrm{H}_{0}$ ) dan nilai probabilitas Lagrange Multiplier (error) sebesar 0,075 (gagal tolak $\mathrm{H}_{0}$ ). Artinya, terjadi dependensi spasial pada lag yang menunjukkan bahwa nilai variabel dependen suatu wilayah dipengaruhi oleh nilai variabel dependen di wilayah sekitarnya, serta tidak terjadi dependensi spasial pada error yang menunjukkan bahwa nilai variabel dependen di suatu wilayah tidak dipengaruhi oleh nilai variabel error di wilayah sekitarnya. Oleh karena itu, Spatial Autoregressive Model dinilai lebih tepat digunakan dalam menjelaskan dependensi spasial pada penelitian ini dibandingkan dengan Spatial Error Model. Sehingga, penelitian ini akan menggunakan Spatial Autoregressive Modelatau SAR untuk mengestimasi parameter.

Tabel 3. Output GeoDa untuk identifikasi pengaruh dependensi spasial.

\begin{tabular}{lrrcc}
\hline \multicolumn{1}{c}{ Uji Dependensi Spasial } & \multicolumn{1}{c}{ Mi/df } & \multicolumn{1}{c}{ Nilai } & \multicolumn{1}{c}{$p$-value } & Keputusan \\
\hline (1) & \multicolumn{1}{c}{$(2)$} & \multicolumn{1}{c}{$(3)$} & \multicolumn{1}{c}{$(4)$} & $(5)$ \\
Moran's I (error) & 0,170 & 2,482 & $0,013^{*}$ & Tolak Ho \\
Lagrange Multiplier (lag) & 1 & 14,110 & $0,000^{*}$ & Tolak $\mathrm{H}_{0}$ \\
Robust LM (lag) & 1 & 16,230 & $0,000 *$ & Tolak $\mathrm{H}_{0}$ \\
Lagrange Multiplier (error) & 1 & 3,174 & 0,075 & Gagal Tolak $\mathrm{H}_{0}$ \\
\hline
\end{tabular}

Keterangan: *) signifikan pada $a=5$ persen

Pemodelan Regresi Spatial Autoregressive Model

Tabel 4. $\quad$ Ringkasan hasil estimasi parameter regresi Spatial Autoregressive Model.

\begin{tabular}{lrrrr}
\hline \multicolumn{1}{c}{ Variabel } & \multicolumn{1}{c}{ Koefisien } & Standard error & \multicolumn{1}{c}{-value } & Probabilitas \\
\hline \multicolumn{1}{c}{$(1)$} & \multicolumn{1}{c}{$(2)$} & \multicolumn{1}{c}{$(3)$} & \multicolumn{1}{c}{$(4)$} & $(5)$ \\
Intersep & 729.335 & 275.662 & 2,646 & $0,008^{*}$ \\
AK & $-0,937$ & 0,265 & $-3,545$ & $0,000^{*}$ \\
Peng_Perka & 0,028 & 0,009 & 3,056 & $0,002^{*}$ \\
Eko & 29.278 & 13615,9 & 2,150 & $0,032^{*}$ \\
PDRB & 3,820 & 1,227 & 3,114 & $0,002^{*}$ \\
W_UMK & 0,519 & 0,115 & 4,512 & $0,000^{*}$
\end{tabular}

Keterangan: *) signifikan pada $a=5$ persen 
Tabel 4 menunjukkan bahwa keempat variabel independen yaitu variabel jumlah angkatan kerja (AK), pengeluaran per kapita (Peng_Perka), pertumbuhan ekonomi (Eko), dan PDRB berpengaruh secara signifikan terhadap Upah Minimum Kabupaten/Kota di Pulau Kalimantan tahun 2017. Dari Tabel 4 juga dapat dilihat bahwa nilai koefisien W_UMK memiliki nilai probabilitas sebesar 0,000 yang artinya variabel dependen berpengaruh secara signifikan terhadap variabel dependen wilayah lain di sekitarnya. Selain itu, nilai $R$-squared dari model tersebut adalah sebesar 0,591 yang menunjukkan bahwa model regresi SAR dengan variabel jumlah angkatan kerja, pengeluaran per kapita, pertumbuhan ekonomi, dan PDRB dapat menjelaskan 59,1 persen dari Upah Minimum Kabupaten/Kota di Pulau Kalimantan tahun 2017. Berdasarkan hasil di atas, diperoleh estimasi model SAR yang menggambarkan Upah Minimum Kabupaten/Kota di Pulau Kalimantan tahun 2017 sebagai berikut:

$$
\begin{aligned}
\widehat{U M K}_{\iota}= & 0,519 \sum_{j=1 ; i \neq j}^{56} w_{i j} U M K_{j} 729.335^{*}-0,937 \text { AK }_{i}{ }^{*}+0,028 \text { Peng_Perka }_{i}{ }^{*}+29.278 \text { Eko }_{i}{ }^{*}+ \\
& 3,820 \operatorname{PDRB}_{i}{ }^{*}
\end{aligned}
$$

Keterangan:

$\widehat{U M K}_{l} \quad$ : estimasi parameter Upah Minimum Kabupaten/Kota ke-i

$U M K_{i}$ : Upah Minimum Kabupaten/Kota ke-j, di mana $\mathrm{i} \neq \mathrm{j}$ dan $\mathrm{j}$ adalah semua tetangga $\mathrm{i}$

$w_{i j} \quad$ : nilai elemen matriks penimbang spasial antar kabupaten/kota

$A K_{i} \quad$ : jumlah angkatan kerja kabupaten/kota ke-i

Peng_Perka $a_{i}$ : pengeluaran per kapita kabupaten/kota ke-i

$E k o_{i} \quad$ : pertumbuhan ekonomi kabupaten/kota ke-i

$P D R B_{i}$ : PDRB kabupaten/kota ke-i

Berdasarkan persamaan yang terbentuk di atas, jika secara rata-rata Upah Minimum Kabupaten/Kota di sekitarnya meningkat satu satuan dan seluruh variabel independen konstan, maka akan menaikkan nilai upah minimum suatu kabupaten/kota sebesar 0,519. Hal ini menunjukkan bahwa upah minimum suatu wilayah memengaruhi upah minimum wilayah di sekitarnya.

Selain itu, upah minimum suatu kabupaten/kota akan turun sebesar 0,937 satuan jika jumlah angkatan kerja suatu kabupaten/kota meningkat satu satuan apabila variabel pengeluaran per kapita, pertumbuhan ekonomi, PDRB, serta pengaruh spasial dari variabel dependen dianggap konstan.

Sementara itu, peningkatan pada pengeluaran per kapita suatu kabupaten/kota signifikan menaikkan upah minimum sebesar 0,028 satuan dengan mengasumsikan jumlah angkatan kerja, pertumbuhan ekonomi, PDRB, serta pengaruh spasial dari variabel dependen dianggap konstan. Hasil ini sesuai dengan penelitian Nurtiyas (2016) bahwa pendapatan per kapita berpengaruh signifikan secara positif terhadap upah minimum suatu daerah, di mana dalam penelitian ini pendapatan per kapita didekati dengan pengeluaran per kapita.

Peningkatan pada pertumbuhan ekonomi juga berpengaruh secara signifikan dengan menaikkan upah minimum suatu kabupaten/kota sebesar 29.278 satuan dengan mengasumsikan jumlah angkatan kerja, pengeluaran per kapita, PDRB, serta pengaruh spasial dari variabel dependen adalah konstan. Hasil ini sesuai dengan penelitian Charysa, bahwa pertumbuhan ekonomi berpengaruh positif terhadap upah minimum kabupaten/kota.

Selanjutnya, PDRB di suatu kabupaten/kota juga secara signifikan akan meningkatkan upah minimum kabupaten/kota tersebut sebesar 3,820 satuan, dengan asumsi jumlah angkatan kerja, pengeluaran per kapita, pertumbuhan ekonomi, serta pengaruh spasial dari variabel dependen adalah konstan. Hasil ini sesuai dengan penelitian Nursakinah (2017) dan Kistanto (2013) bahwa PDRB berpengaruh signifikan secara positif terhadap upah minimum suatu daerah.

\section{KESIMPULAN}

Berdasarkan hasil analisis dan pembahasan yang telah diuraikan, maka dapat ditarik kesimpulan bahwa pada tahun 2017, sebesar 76,79 persen kabupaten/kota yang berada di Pulau Kalimantan memiliki Upah Minimum Kabupaten/Kota melebihi upah minimum nasional. Kemudian berdasarkan hasil pengujian spasial melalui Global Moran's I, diketahui terdapat autokorelasi spasial yang positif 
antar kabupaten/kota pada karakteristik Upah Minimum Kabupaten/Kota di Pulau Kalimantan pada tahun 2017. Hal ini berarti kabupaten/kota dengan besaran upah yang tinggi cenderung dikelilingi oleh kabupaten/kota dengan besaran upah yang tinggi pula, begitu pun sebaliknya. Selanjutnya berdasarkan pengujian koefisien autoregresif spasial dan autokorelasi spasial, diperoleh koefisien autoregresif spasial yang signifikan. Hasil ini menunjukkan bahwa model yang terpilih adalah spasial lag, yang menyatakan adanya ketergantungan pada variabel dependen. Hal ini berarti nilai upah minimum di suatu kabupaten/kota dipengaruhi oleh nilai upah minimum di kabupaten/kota sekitarnya. Spatial Autoregressive Model (SAR) menunjukkan bahwa terdapat empat variabel yang secara signifikan berpengaruh terhadap Upah Minimium Kabupaten/Kota di Pulau Kalimantan, yaitu jumlah angkatan kerja, pengeluaran per kapita, pertumbuhan ekonomi, dan PDRB.

\section{UCAPAN TERIMA KASIH}

Terima kasih penulis ucapkan kepada semua pihak yang telah membantu penulis dalam melakukan penelitian ini, khususnya kepada Bapak Dr. Timbang Sirait, S.Stat., M.Si., sebagai dosen pembimbing yang telah meluangkan waktu dan dengan sabar mengarahkan dan membimbing penelitian ini; serta kedua orang tua yang selalu memberikan dorongan semangat dan dukungan penuh kepada penulis.

\section{DAFTAR PUSTAKA}

Anselin, Luc. (1988). Spatial Econometrics: Methods and Models. London: Kluwer Academic Publishers. . (2003). "Spatial Econometrics". Dalam Baltagi, Badi H (Ed). (2003). A Companion to Theoretical Econometrics. Oxford: Blackwell Publishing.

. (2005). Exploring Spatial Data with GeoDa: A Workbook. Urbana: Center for Spatial Integrated Social Science.

Badan Pusat Statistik Provinsi Kalimantan Barat. (2018). Provinsi Kalimantan Barat Dalam Angka 2018. Pontianak: BPS.

Badan Pusat Statistik Provinsi Kalimantan Selatan. (2018). Provinsi Kalimantan Selatan Dalam Angka 2018. Banjarbaru: BPS.

Badan Pusat Statistik Provinsi Kalimantan Tengah. (2018). Provinsi Kalimantan Tengah Dalam Angka 2018. Palangka Raya: BPS.

Badan Pusat Statistik Provinsi Kalimantan Timur. (2018a). Provinsi Kalimantan Timur Dalam Angka 2018. Samarinda: BPS. . (2018b). Provinsi Kalimantan Utara Dalam Angka 2018. Samarinda: BPS.

Badan Pusat Statistik. (2018a). Statistik Indonesia 2018. Jakarta: BPS.

(2018b). Tinjauan Regional Berdasarkan PDRB Kabupaten/Kota 2013-2017 - Buku 3 Pulau Kalimantan. Jakarta: BPS.

Biaya dan Tarif. (2016a). Daftar UMK Kaltara 2017. https://www.biaya.net/2016/01/daftar-umk-kalsel2016.html?m=1. [13 Mei 2019]

(2016b). UMK dan Upah Sektoral Kalimantan Tengah 2018. https://www.biaya.net/2015/11/umk-kabupatenkota-kalimantan-tengah-2016.html?m=1. [13 Mei 2019] . (2016c). UMK dan Upah Sektoral Kaltim 2018. https://www.biaya.net/2016/01/umk-kaltim2016.html?m=1. [13 Mei 2019]

Mei 2019] (2016d). UMK Kalsel 2017. https://www.biaya.net/2016/01/umk-kalsel-2016.html?m=1. [13

(2016e). Upah Minimum Kabupaten/Kota UMK di Kalbar 2017. 2019 melalui https://www.biaya.net/2016/01/upah-minimum-kabupaten-kota-umk-dikalbar-2016.html?m=1. [13 Mei 2019]

Charysa, Ninda Noviani. (2013). Pengaruh Pertumbuhan Ekonomi dan Inflasi terhadap Upah Minimum Regional di Kabupaten/Kota Provinsi Jawa Tengah Tahun 2008-2011, Economics Development analysis Journal Vol. 2 No. 4, 2013. Semarang: Universitas Negersi Semarang.

Goodchild, Michael. Methods: First Law of Geography. Santa Barbara: University of California.

Kamus Besar Bahasa Indonesia. (2016a). KBBI Daring. Dikutip dalam https://kbbi.kemdikbud.go.id/entri/kesejahteraan. [31 Juli 2019] 2019]

Kistanto, Ilham. (2013). Analisis Penetapan Upah Minimum Kabupaten di Jember. Skripsi Universitas Jember. Jember. $62 \mathrm{hlm}$.

Neter et al. (1989). Applied Linear Regression Models. Boston: Irwin. 
Nursakinah, Eka. (2017). Analisis Faktor-Faktor yang Mempengaruhi Penetapan Upah Minimum di Jabodetabek Tahun 2007-2016. Yogyakarta: Universitas Islam Negeri Sunan Kalijaga Yogyakarta.

Nurtiyas, Febrika. (2016). Analisis Faktor-Faktor yang Mempengaruhi Upah Minimum Propinsi di Pulau Jawa Tahun 2010-2014, Vol. 5 No. 2, 2016, 166-175. Yogyakarta: Universitas Negeri Yogyakarta.

United Nation. (2017). Tujuan SDG. Dikutip dalam https://www.sdg2030indonesia.org/page/1-tujuan-sdg. [17 Mei 2019] 